\title{
SAME-Sex MARRIAge AND the SAME Old Constitution*
}

\author{
Ronalda Murphy
}

\section{INTRODUCTION}

The Reference re Same-Sex Marriage ${ }^{1}$ is not a major opinion on the rights of same-sex couples in Canada, but it is nonetheless an important and fascinating case. There are only a few lines that are about the "rights" of same-sex couples. Did the Supreme Court of Canada "duck" the issue? Was the Court carefully gauging how much or little political capital it had and making a political decision to say as little as possible on this topic? The Court certainly displayed strategic brilliance, but it did not do so in the name of avoiding the "political" hot topic of same-sex marriage. It is factually difficult to maintain the view that the Supreme Court of Canada is loath to enter into this political debate. It has been the lead social institution in Canada in terms of responding to the claims of gays and lesbians to equality in law, ${ }^{2}$ and it has never been shy of dealing with topics simply because they involve controversial political issues. ${ }^{3}$ Rather, the Court's brilliance lies in its minimalist and almost weary tone. This approach had the effect of taking the wind out of the sails of those opposed to same-sex marriage: the same-sex advocates definitely win the constitutional race,

* Thanks to Thom Yachnin for great last-moment research assistance, to William and Jim for getting married and inspiring this comment.

[2004] 3 S.C.R. 698, 2004 SCC 79, online: CanLII $<$ http://www.canlii.org/ca/cas/scc/2004/2004scc79.html> [Same-Sex Reference].

See generally, Vriend v. Alberta, [1998] 1 S.C.R. 493, online: CanLII <http://www.canlii.org/ca/cas/scc/1998/1998scc30. html> [Vriend]; and Egan v. Canada, [1995] 2 S.C.R. 513, online: CanLII <http://www.canlii.org/ca/cas/scc/1995/ $1995 \mathrm{scc} 49 . \mathrm{html}>$ [Egan $]$.

Two such cases that I discuss in this comment are Reference re Secession of Quebec, [1998] 2 S.C.R. 217, online: CanLII <http://www.canlii.org/ca/cas/scc/1998/1998scc63.html> [Quebec Secession Reference]; and Sauvé v. Canada (Chief Electoral Officer), [2002] 3 S.C.R. 519, 2002 SCC 68, online: CanLII <http://www.canlii.org/ca/cas/scc/2002/2002scc68. html $>$ [Sauvé]. but they do so because according to the Supreme Court, there is no provincial constitutional headwind that can stop them. In short, provinces can complain all they want about the federal position in favour of same-sex marriage, but the wedding will go on despite and over their objections to the ceremony.

I begin the comment with a description of the two key legal issues, federalism and rights. I explain why the Supreme Court's resolution of these issues is correct and provide a critical analysis of the opinion, focussing on three questions: Is anything "natural" in law? Where does the content of rights come from? And finally, do we have reasonable expectations of constitutions and their interpreters?

\section{BACKGROUND AND HOLDING}

On 16 July 2003, pursuant to section 53 of the Supreme Court Act, ${ }^{4}$ the Governor in Council issued an order in council referring the following questions to the Supreme Court of Canada with regard to the federal government's proposed legislation providing for same-sex marriage:

1. Is the annexed Proposal for an Act respecting certain aspects of legal capacity for marriage for civil purposes within the exclusive

Supreme Court Act, R.S.C. 1985, c. S-26, s. 53(1) provides:

53. (1) The Governor in Council may refer to the Court for hearing and consideration important questions of law or fact concerning...

(d) the powers of the Parliament of Canada, or of the legislatures of the provinces, or of the respective governments thereof, whether or not the particular power in question has been or is proposed to be exercised. 
legislative authority of the Parliament of Canada? If not, in what particular or particulars, and to what extent?

2. If the answer to question 1 is yes, is section 1 of the proposal, which extends capacity to marry to persons of the same sex, consistent with the Canadian Charter of Rights and Freedoms? If not, in what particular or particulars, and to what extent?

3. Does the freedom of religion guaranteed by paragraph 2(a) of the Canadian Charter of Rights and Freedoms protect religious officials from being compelled to perform a marriage between two persons of the same sex that is contrary to their religious beliefs?

4. Is the opposite-sex requirement for marriage for civil purposes, as established by the common law and set out for Quebec in section 5 of the Federal Law - Civil Law Harmonization Act, No. 1, consistent with the Canadian Charter of Rights and Freedoms? If not, in what particular or particulars and to what extent? ${ }^{5}$

The operative sections of the proposed legislation read as follows:

1. Marriage, for civil purposes, is the lawful union of two persons to the exclusion of all others.

2. Nothing in this Act affects the freedom of officials of religious groups to refuse to perform marriages that are not in accordance with their religious beliefs. $^{6}$

P.C. 2003-1055. The fourth question was added on 26 January 2004 , by a second order in council that amended the first: Amendment to Order in Council 2003-1055, P.C. 2004-28. See also Same Sex Reference, supra note 1 at paras. 2-3.

Department of Justice Canada, Press Release, "Reference to the Supreme Court of Canada" (17 July 2003), online: Department of Justice Canada <http://canada.justice.gc.ca/en/news/nr/ 2003/doc30946.html>. See also Same-Sex Reference, ibid. at
On 9 December 2004 the Supreme Court of Canada held that under section 91(26) of the Constitution Act, $1867,{ }^{7}$ the federal government has legislative authority to pass laws in relation to marriage, and that case law has consistently held that this authority includes laws on the capacity to marry. According to the Court, extending the definition of civil marriage to include same-sex couples is a law regulating the "capacity" to marry, which falls within the federal power to legislate in relation to marriage. As such, section 1 of the proposed Act is intra vires the federal government. What the federal government cannot do is regulate non-marital relationships. Further, the Court held that section 2 of the proposed Actoffering religious freedom rights for those solemnizing marriage - is not a law in relation to marriage but rather one regarding its "solemnization," a subject matter that is allocated to the provinces under section 92(12) of the Constitution Act, 1867. Section 2 of the proposed Act was therefore held to be ultra vires Parliament.

The heart of the decision on these points is contained in the following passage in which the Court rejected the logic that would support provincial law on marriage:

Marriage and civil unions are two distinct ways in which couples can express their commitment and structure their legal obligations. Civil unions are a relationship short of marriage and are, therefore, provincially regulated. The authority to legislate in respect of such conjugal relationships cannot, however, extend to marriage. If we accept that provincial competence in respect of samesex relationships includes same-sex marriage, then we must also accept that provincial competence in respect of opposite-sex relationships includes opposite-sex marriage. This is clearly not the case. Likewise, the scope of the provincial power in respect of solemnization cannot reasonably be extended so as to grant jurisdiction over

paras. 15,35 .

(U.K.), 30 \& 31 Vict., c.3, reprinted in R.S.C. 1985, App. II, No. 5 . 
same-sex marriage to the provincial legislatures. Issues relating to solemnization arise only upon conferral of the right to marry. Just as an opposite-sex couple's ability to marry is not governed by s. 92 (12), so a same-sex couple's ability to marry cannot be governed by s. 92(12). ${ }^{8}$

These are the "federalism" parts of the opinion. The "trite law" on a federalism question is that first you characterize the subject matter of the law - its "pith and substance," or dominant characteristic. Then you look at the text of the Constitution Act, 1867 and see which of the two levels of government is constitutionally empowered to pass laws on that topic. Section 91 is the federal list, and section 92 is the provincial one. ${ }^{10}$

In many cases, this two-step process is actually harder than it sounds; otherwise, constitutional law would be an easier course to take or to teach. It is simply not obvious what falls within or beyond the federal power to regulate "trade and commerce" (under section 91(2)) or the provincial power over "property and civil rights" (under section 92(13)). These are deliberately large and vague phrases, and case law provides the only way to undertake such an analysis. Alternative sources of jurisdiction are argued in many cases, and in no case is an analysis under step one undertaken by a litigant or a judge without knowing the effect of the characterization under step two. So it is not really a two-step dance, despite the triteness of the law. It is one step: develop an argument about characterization that triggers a particular head of power. If you are is seeking to argue for a federal law, you say that in pith and substance the law is one that $\mathrm{X}$, where $\mathrm{X}$ matches a federal head of power as defined through case law under step two. To challenge a federal law, argue for a pith and substance that maps onto decided cases regarding provincial power. ${ }^{11}$ Every law has to belong to either one or

Same-Sex Reference, supra note 1 at para. 33

Ibid. at para. 13 .

10 There are other sources of legislative authority in the Constitution Act, 1867 but ss. 91-92 are the primary sources.

11 For example, if there is a law regulating transactions, and you want to find federal authority, you will characterize the law as one governing interprovincial and international trade, or a law regulating the economy as a whole. Opposing arguments would focus on the intraprovincial dimensions of the transaction being targeted so as to trigger the property and civil rights head of the other level of government, and while sometimes both levels can pass a law in relation to the same subject matter, those laws will be pursuant to different "heads" of power. ${ }^{12}$

There is nothing within the principles of federalism that constrains the content of a law. Each level of government can pass any law they want as long as the "pith and substance" of the law is a subject matter that falls within their legislative authority under the Constitution Act, 1867. By contrast, constitutional rights do operate to limit what a government can say or do in a law, limiting both the federal and provincial levels of government in exactly the same way.

The rights issues in the Same-Sex Reference are triggered by reference questions two through four. Question two asked whether it is consistent with the Charter ${ }^{13}$ to extend marriage to same-sex couples, and the Court answered yes for several reasons. First, the proposed law is a direct legislative response to several appellate-level decisions that the opposite-sex requirement for civil marriage violates section $15(1)$ of the Charter, which guarantees equality. ${ }^{14}$ Moreover, while not at all determinative of validity, the

provincial power.

This is the principle of exhaustiveness, explained by the Court, supra note 1 at para. 34 as follows [citations omitted]:

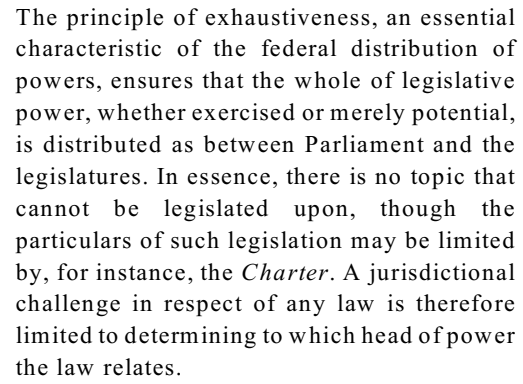

3 Part I of the Constitution Act, 1982, being Schedule B to the Canada Act 1982 (U.K.), 1982, c.11 [Charter].

14 Same Sex Reference, supra note 1 at para. 41 . The Court cites the following cases: EGALE Canada v. Canada (A.G.) (2003), 225 D.L.R. (4th) 472, 2003 BCCA 251, online: CanLII $<$ http://www.canlii.org/bc/cas/bcca/2002/2002bcca396.html>; Halpern v. Canada (A.G.) (2003), 65 O.R. (3d) 161 (C.A.), online: CanLII <http://www.canlii.org/on/cas/onca/ 2003/2003onca10314.html>; and Hendricks v. Québec (P.G.), [2002] R.J.Q. 2506 (Sup. Ct.), online: CanLII <http:// www.canlii.org/qc/jug/qccs/2002/2002qccs14544.html>. More recent cases to the same effect are: Dunbar v. Yukon (2004), 8 R.F.L. (6th) 235, 2004 YKSC 54, online: CanLII <http:// www.canlii.org/yk/cas/yksc/2004/2004yksc54.html>; and Boutilier v. Nova Scotia (A.G.), [2004] N.S.J. No. 357 (S.C.) (QL). 
instructive preamble of the proposed Act offers Charter compliance as the motivation for the law, ${ }^{15}$ and the policy of the federal government has been to address the equality concerns of samesex couples. Finally, neither the religious nor the equality rights of those opposed to same-sex marriage are impermissibly affected by the proposed law:

The mere recognition of the equality rights of one group cannot, in itself, constitute a violation of the rights of another. The promotion of Charter rights and values enriches our society as a whole and the furtherance of those rights cannot undermine the very principles the Charter was meant to foster. ${ }^{16}$

Question three asked whether section 2(a) of the Charter, which guarantees freedom of religion, protects religious officials from being compelled to perform same-sex marriages contrary to their religious beliefs. The Court considered this question as it applies to the performance of both

15 Obviously, it is not enough to state that a law has a constitutionally permissible preamble in order to establish constitutionality. If this were adequate, all the legislative authorities would need to do is write perfect preambles to prevent their legislation from being struck down by the courts. The same is true of any declaratory provision. See Same-Sex Reference, supra note 1 at para. 38:

While it is true that Parliament has exclusive jurisdiction to enact declaratory legislation relating to the interpretation of its own statutes, such declaratory provisions can have no bearing on the constitutional division of legislative authority. That is a matter to be determined, should the need arise, by the courts. It follows that a federal provision seeking to ensure that the Act within which it is situated is not interpreted so as to trench on provincial powers can have no effect and is superfluous.

The preamble at issue in this case states (ibid. at para. 42):

WHEREAS, in order to reflect values of tolerance, respect and equality consistent with the Canadian Charter of Rights and Freedoms, access to marriage for civil purposes should be extended to couples of the same sex;

AND WHEREAS everyone has the freedom of conscience and religion under the Canadian Charter of Rights and Freedoms and officials of religious groups are free to refuse to perform marriages that are not in accordance with their religious beliefs[.]

16 Ibid. at para. 46. religious and civil marriages by religious officials and answered yes, but indicated that under the federalism principles discussed above, it was for the provinces to ensure that freedom of religion was protected. This makes sense: the provinces have both the power to pass laws in relation to solemnization and the civil rights of provincial citizens. As the Court stated, "it would be for the Provinces, in the exercise of their power over the solemnization of marriage, to legislate in a way that protects the rights of religious officials while providing for solemnization of same-sex marriage." 17 The Court further noted that, logically, the same reasoning would preclude the compulsory use of sacred places for the celebration of such marriages and being compelled to otherwise assist in the celebration of same-sex marriages. Any law that compelled the practice of religious rites contrary to religious beliefs could not be justified under section 1 of the Charter. ${ }^{18}$ Protection of religious freedom is effectively mandatory, but it is only the provinces that can offer it; the rights and freedoms contained in the Charter regulate the content of law, while the division of legislative jurisdiction under the Constitution Act, 1867 regulates the author.

Question four was added on 26 January $2004 .{ }^{19}$ It asked whether restricting marriage to opposite-sex couples is consistent with the Charter. As noted, several courts had already said it is not. ${ }^{20}$ The federal government chose to not appeal those decisions. They chose, in other words, to not find out what the Supreme Court of Canada might say despite several perfect opportunities to do so, and despite the advantages of doing so in the context of a typical adversarial forum. While it is possible the Supreme Court of Canada may have denied leave in any of those cases, it is highly unlikely given the nature of the law at issue (federal common law) and that it was on a subject (marriage) for which national uniformity was desirable (it was allocated to the federal government not the provincial ones in the

\footnotetext{
17 Ibid. at para. 55. The Court added its usual caution: "absent exceptional circumstances which we cannot at present foresee." I say usual because it has taken to doing this in relation to s. 7 cases as well; see e.g., United States v. Burns, [2001] 1 S.C.R. 283 at para. 8, 2001 SCC 7, online: CanLII <http://www. canlii.org/ca/cas/scc/2001/2001scc7.html>.

18 Same-Sex Reference, ibid. at paras. 56, 58.

19 See supra note 5.

20 See supra note 14
} 
Constitution Act, 1867). So it matters that leave to appeal was not even sought by the party (the federal government) that lost these cases at the lower levels of court.

The Supreme Court of Canada did not answer question four because the Court felt the federal strategy was Janus-faced. There are many reasons for sending a reference, but it is usually because the government needs the "advice" of the Court and cannot otherwise obtain it in a thorough and inclusive manner. Typically, a reference serves to short-circuit and speed up the normal litigation process. In the same-sex cases, however, the opposite occurred. The underlying cases were not appealed in a context where leave to appeal would likely have been granted. Instead, thousands of same-sex couples were married across Canada (their marriage was legal in five provinces and one territory at the date of the Supreme Court of Canada's opinion), ${ }^{21}$ and the reference threatened those marriages by inviting the highest Court to reject the reasoning that had secured their legal entitlement to marry. More significantly, counsel on the Same-Sex Reference advised the Supreme Court that the federal government was going to proceed with the legislation extending the right to marry to same-sex couples regardless of the Court's answer to the questions. Whether or not the Court felt the federal government was trying to deflect responsibility for the political issue to the Court, it was certainly entitled to feel misused by the federal government in being asked to answer an essentially moot question. The Court refused to answer on the logical basis that any advice it might choose to provide could be in favour or against the federal view of the matter (regarding whether the Charter required that same-sex couples have access to the institution of marriage). As such, the advice might unfairly disrupt the legal security that attached to those already married under decisions that were not appealed, and would not be followed if it departed from the government's policy to extend rights to same-sex couples. ${ }^{22}$

\section{ANALYSIS}

The Same-Sex Reference opinion is a constitutional law professor's dream case. It is a short, clear, unanimous opinion of the highest court in the land on the interpretation of the basic constitutional documents of the country: the 1867 Constitution Act and the 1982 Charter of Rights and Freedoms.

After reminding us of the basic dimensions of federalism and its supporting doctrines (pith and substance, incidental effects, exhaustiveness), the Court reiterated the now-familiar proposition that under a constitutional supremacy, rights are intended to operate as a constraint on legislative choices. Both the Constitution Act, 1867 and the rights and freedoms contained in the Charter were given their usual purposive interpretation. All fairly standard stuff. ${ }^{23}$ The only new legal point in the case is with respect to the Court's interpretation of its discretion to not answer a reference question. The Court had previously stated that it was not required to answer a nonjusticiable question simply because it came in the form of a reference, and that it can properly (if unusually) refuse to answer where that answer would be incomplete or inaccurate because of a problem with either the framing of the question or the supporting information. ${ }^{24}$ In this case it added a new basis for refusing to answer: if you are not actually interested in hearing what we think, we will not bother telling you.

23 In the course of its usual rejection of the framer's intent as governing constitutional interpretation, the Court noted that in cases where it has referred to the framer's intent, it is with reference to a particular constitutional agreement as opposed to a head of power. The former has to be correctly divined; the latter has to be interpreted for the future (see ibid. at para. 30). I like, but am not completely convinced by, this distinction. Agreements are behind every phrase in a constitution. I think that a better distinction, and one I use to explain to my students the divergence in case law on the issue of framer's intent, is one between constitutional provisions that create structural institutions, and provisions that assign heads of power between the two levels of government. Structural cases are those that relate to federal courts, s. 96 appointment powers, the Senate, denominational schools, etc. These need not be interpreted with a view to the future as much as to maintaining expectations as to what was intended by creating a certain framework within which state power would then flow.

24 Ibid. at para. 10, citing as examples: Reference re Canada Assistance Plan (British Columbia), [1991]2 S.C.R. 525 at 545, online: CanLII <http://www.canlii.org/ca/cas/scc/1991/ 1991scc66.html>; Reference re Objection by Quebec to a Resolution to Amend the Constitution, [1982] 2 S.C.R. 793 at 806; and Quebec Secession Reference, supra note 3 at paras. 26-30, 62-63. 
This summer, while contemplating where to place this case within my constitutional law teaching materials, I realized that I cannot really put it in a section with other gay and lesbian constitutional cases because there are only a few non-pithy sentences on same-sex rights. I think I will end up putting the Same-Sex Reference right at the beginning of my course materials, immediately after lengthy excerpts from the Quebec Secession Reference opinion. There are many structural similarities between the two cases. Both are the result of references; there were cries of political foul play against the federal government with respect to both questions; ${ }^{25}$ both concern socially controversial and divisive political subjects; and both deal with federalism and rights, issues that form the bulk of what is taught in a year long course on constitutional law.

I like beginning with the Quebec Secession Reference because it is evocative and stirring. It is the Court at its most passionate, elegant, and elaborate. Even seasoned constitutional law professors found many things that were new in the case - such as the four unwritten constitutional principles that have apparently been there all along and just newly articulated. ${ }^{26}$ It is heady, meaty stuff. Some students are actually excited about constitutional law, and all like to see that, as future lawyers, they will be the ones that provide the Court with arguments and interpretations of what the law is and should be. If the Court finds those claims persuasive, a lawyer can find her analysis adopted. In this way, students understand that they have a significant role to play: it is not merely judges and legislators who create law in a constitutional democracy.

Another fascinating aspect of the Quebec Secession Reference is that students quickly adapt to and adopt the loaded imagery of that decision. ${ }^{27}$

\footnotetext{
25 See M. André Joli-Coeur, "Factum of the Intervener Amicus Curiae" (1998) [unpublished, on file with the author]. In the Quebec Secession Reference, the issue was the wording of the question (whether Quebec could "unilaterally" secede from Canada), whereas in the Same-Sex Reference, the issue was the late addition of the fourth question.

26 These are federalism (Quebec Secession Reference, supra note 3 at paras. 55-60), democracy (at paras. 61-69), constitutionalism and the rule of law (at paras. 70-78), and protection of minorities (at paras. 79-82).

27 Ibid. at paras. 49-52. Note the many metaphors at work [emphasis added]:
}

What are those underlying principles? Our
Within a few classes, arguments invoking the "lifeblood/foundation/architecture" metaphors become familiar. But it takes much longer for students to really grasp the difference between a simplistic concept of democracy that says that majority might makes right (rejected in Canada), and a complex notion of a constitutional democracy that intentionally and justly precludes majorities from running roughshod over the rights of minorities (reflected in the Canadian Constitution). I ask them to go back and reread the case at the end of the academic year, after they have learned many minority rights, to see if they now understand what the Court meant by the injustice of a conception of democracy that allows majorities to dictate the rights, if any, of the numerical minorities.

Constitution is primarily a written one, the product of 131 years of evolution. Behind the written word is an historical lineage stretching back through the ages, which aids in the consideration of the underlying constitutional principles. These principles inform and sustain the constitutional text: they are the vital unstated assumptions upon which the text is based...

Our Constitution has an internal architecture, or what the majority of this Court in $O P S E U$ v. Ontario (Attorney General), [1987] 2 S.C.R. 2, at p. 57, called a "basic constitutional structure". The individual elements of the Constitution are linked to the others, and must be interpreted by reference to the structure of the Constitution as a whole. As we recently emphasized in the Provincial Judges Reference Reference, certain underlying principles infuse our Constitution and breathe life in to it. ...

Although these underlying principles are not explicitly made part of the Constitution by any written provision, ... it would be impossible to conceive of our constitutional structure without them. The principles dictate major elements of the architecture of the Constitution itself and are as such its lifeblood.

The principles assist in the interpretation of the text and the delineation of spheres of jurisdiction, the scope of rights and obligations, and the role of our political institutions. Equally important, observance of and respect for these principles is essential to the ongoing process of constitutional development and evolution of our Constitution as a "living tree," to invoke the famous description in Edwards v. AttorneyGeneral for Canada, [1930] A.C. 124 (P.C.), at p. 136. 
An especially fascinating aspect of the Court's decision in the Quebec Secession Reference is that despite the boldness and innovation in the case, both the federal and Quebec governments saw it as a victory. So the Same-Sex Reference should be a perfect pair to the Quebec Secession Reference. Is it not the perfect illustration of the principles articulated in the latter case? But herein lies the rub. The Same-Sex Reference is the Court at its most dull and detached. Everyone came away with less than they wanted and, in an odd way, no one felt that they had "won." 28 The provincial governments were told in no uncertain terms that they simply cannot pass laws relating to access to marriage because they have no power to pass laws on the capacity to marry. The federal government was told it could pass any law it wanted to relating to marriage and capacity to marry, but it can neither pass a law relating to the rights of those empowered by the province to solemnize marriages nor regulate non-marital relationships. The interveners were told that all laws must comply with the constitution; marriage may or may not be "natural," 29 but in Canada, it has to be constitutional. Same-sex marriage advocates were told that the proposed law "flowed" from the Charter,${ }^{30}$ but not that the Charter compelled that the law be proposed.

Notwithstanding the media attention and national debate surrounding the case, the SameSex Reference is arguably the least exciting constitutional decision ever written. There is not a single new metaphor. There is no conceptualization of the issues or relationships at stake; it is all straightforward application. In a word, it is boring. Does that make it bad constitutional law? What do "we" want from the Court in these high-profile constitutional cases, and do we need what we want?

In this comment I attempt to answer these questions by exploring three related themes generated by this case. First, I consider the terms "natural" and "inherent" in constitutional law and show how these concepts were used in this case, asserting that the Court's response was somewhat problematic. Second, I ask where the content of

28 See e.g., Katherine Harding, "Alberta Plans to Fight Gay Marriage" The Globe and Mail (10 December 2004) A 8 .

29 See discussion beginning in the next section, below.

$30 \quad$ Same-Sex Reference, supra note 1 at para. 43. rights comes from (constitutions? courts? laws? individual acts of assertion?) in order to make a third and concluding comment about whether our expectations of constitutions and their interpreters are reasonable.

\section{WhAT IS NATURAL OR INHERENT IN CONSTITUTIONAL LAW?}

The interveners argued that the definition of marriage was inherently a union between two members of the opposite sex. This argument supported two claims. One, that the definition of marriage eluded capture in law; its meaning preceded the use of the term "marriage" in the legal document of the constitution, and could not be altered by it. Two, that while Canadian jurisprudence has adopted a "living tree" approach, when Lord Sankey first used that metaphor he qualified it with the concept of "natural limits." 31 In other words, a progressive interpretation does not licence any interpretation; you cannot make a stone into a tree or a same-sex union into a marriage.

The Court's reaction to this argument was equally two-fold. With respect to the first claim, the Court explained that practices often look inherent only because they are customary (a conceptual critique), and then pointed to the presence of opposite-sex marriage in Canada and in other countries (a factual critique). With respect to the second point, the Court stated that it is not required to figure out the natural meaning of concepts such as marriage in an abstract fashion; rather, it is merely required to figure out whether a proposed meaning is within the constitutional head of power in issue. In reaching the conclusion

Speaking for the Privy Council in Edwards v. Attorney-General for Canada, [1930] A.C. 124, [1930] 1 D.L.R. 98 (P.C.) [the "Persons" case, cited to A.C.], Lord Sankey L.C. said at 136:

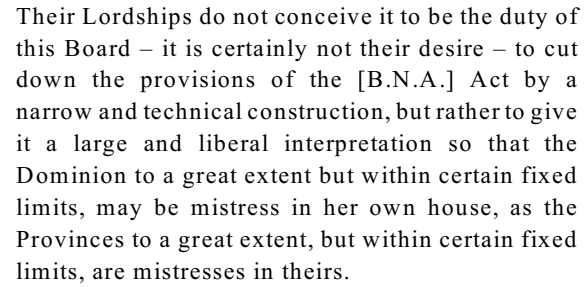

Some interveners emphasized that while Lord Sankey L.C. envisioned our constitution as a "living tree" in the Persons case, he specified that it was "capable of grow th and expansion within its natural limits." 
that the intervener's argument must fail, the Court pointed to the fact of agreement on the proposition that marriage means a union of two people, and the fact of disagreement on whether those two people must be opposite-sex. According to the Court, the fact of disagreement indicates that marriage is not "naturally" limited to opposite-sex couples in its constitutional meaning. Next point.

Before turning to that next point, however, it may be useful to point out what is wrong with this reasoning. Two things immediately come to mind. First, the Court seems to invoke the fact of disagreement about the scope of marriage as the basis for concluding that same-sex couples can be within the meaning of marriage. But is this true? Do we really think that as long as there is some disagreement about what is within marriage that a court will say anything goes? In defence of the Court's reasoning, one could point to the fact that the Court did not say exactly that; indeed, the Court seemed to say that whatever else marriage meant, there was at least consensus that it meant the voluntary union of two adults:

The natural limits argument can succeed only if its proponents can identify an objective core of meaning which defines what is "natural" in relation to marriage. Absent this, the argument is merely tautological. The only objective core which the interveners before us agree is "natural" to marriage is that it is the voluntary union of two people to the exclusion of all others. Beyond this, views diverge. We are faced with competing opinions on what the natural limits of marriage may be. ${ }^{32}$

So in other words, the natural limits of marriage do not admit a third person. Now I might agree that marriage is not a union of three people, but my position is not based on popular opinion. Instead, I would try to explain the good and bad consequences of expanding marriage beyond two people. In other words, neither the fact of disagreement nor the fact of consensus is a terribly powerful argument for or against anything.

Same-Sex Reference, supra note 1 at para. 27.
My second critique of this reasoning is that the Court should simply have rejected the whole idea of naturalness. True, it did not need to do that in this case to respond to the intervener's submission, ${ }^{33}$ but it lost a golden opportunity to make a point that really should be made in the context of the whole marriage debate.

"Natural" and "inherent" are very powerful concepts, but they are at least as difficult to argue for as they are to argue against. The ancient tradition of natural law and the undeniable strategic value of being able to cloak a claim in its gorgeous garb are factors that weigh in favour of attempting to assert the naturalness of a concept. But the natural rights emperor is not wearing any clothes. The constitution did not emerge out of nowhere, or from a transcendent power. Only people can author the claim of naturalness, and history confirms that it is always disputed. The concept of "inherent" suffers the same fate. If things change, then nothing is inherent. It must then always be a conceptual error to claim intellectual immunity for a concept or practice on the basis of its "inherent quality." If it is illogical to assert that anything is inherent, what are we doing by claiming it or allowing it to be claimed?

What do we lose by dropping naturalness and inherency from constitutional discourse? Maybe we would lose something like a sense of constitutional patriotism. In the Quebec Secession Reference the Court's opinion is exciting, in part, because of its explicit invocation of a progress narrative: we constantly strive towards a more perfect protection of the rights. That we failed so

Ibid. at paras. 28-29:

Lord Sankey L.C.'s reference to "natural limits" did not impose an obligation to determine, in the abstract and absolutely, the core meaning of constitutional terms. Consequently, it is not for the Court to determine, in the abstract, what the natural limits of marriage must be. Rather, the Court's role is to determine whether marriage as defined in the Proposed Act falls within the subject matter of s. 91(26).

In determining whether legislation falls within a particular head of power, a progressive interpretation of the head of power must be adopted. The competing submissions before us do not permit us to conclude that "marriage" in s. 91(26) of the Constitution Act, 1867, read expansively, excludes samesex marriage. 
many in the past is beyond dispute. That we improve is equally beyond dispute. But the path is clear, if occasionally blocked, by normative errors that are revealed by history. ${ }^{34}$ However, I believe we can have constitutional narratives that are powerful and useful without having to assert that they are so because they reflect inherent truths. The Supreme Court of Canada has itself acknowledged that "[n]o one has a monopoly on truth, and our system is predicated on the faith that in the marketplace of ideas, the best solutions to public problems will rise to the top." ${ }^{35}$

The logic of inherency is appealing but dangerous: fine if you (or your group identification) are in, dreadful if you are out. Perhaps a better question is not whether rights are inherently one thing or another, but rather what is the source of their content?

${ }^{34}$ See Quebec Secession Reference, supra note 3 at para. 81:

The concern of our courts and governments to protect minorities has been prominent in recent years, particularly following the enactment of the Charter. Undoubtedly, one of the key considerations motivating the enactment of the Charter, and the process of constitutional judicial review that it entails, is the protection of minorities. However, it should not be forgotten that the protection of minority rights had a long history before the enactment of the Charter. Indeed, the protection of minority rights was clearly an essential consideration in the design of our constitutional structure even at the time of Confederation: Senate Reference, [Reference re Authority of Parliament in relation to the Upper House, [1980] 1 S.C.R. 54] at p.71. Although Canada's record of upholding the rights of minorities is not a spotless one, that goal is one towards which Canadians have been striving since Confederation, and the process has not been without successes. The principle of protecting minority rights continues to exercise influence in the operation and interpretation of our Constitution.

35 Ibid. at para. 68. Aboriginal rights have been recognized as inherent by the Supreme Court of Canada in Haida Nation v. British Columbia (Ministry of Forests), [2004] 3 S.C.R. 511 , 2004 SCC 73 at para. 26, online: CanLII <http://www.canlii. $\mathrm{org} / \mathrm{ca} / \mathrm{cas} / \mathrm{scc} / 2004 / 2004 \mathrm{scc} 73 . \mathrm{html}>$. My analysis could be interpreted as threatening the integrity of that positive development. I think there is always a potential problem with "inherent" insofar as it tends to hide the political and social context for the use of the term in relation to particular legal claims. That is not true, however, with respect to aboriginal claims: in the context of Canadian legal history, ironically, the term "inherent" is functioning to reveal the fact that aboriginal communities have not been protected by the Canadian state.

\section{WHERE DOES THE CONTENT OF RIGHTS COME FROM?}

In a constitutional democracy, it is common ground that the judicial branch must be independent of the executive and legislative branches. Without that independence, judges would be afraid to hold the state accountable to the public and require the state to point to a legal source of power for all actions it takes. The separation of powers can be stark or it can be muted, but obviously no constitutional democracy worthy of the label would collapse the branches between the government and the judiciary.

In Canada, the separation is not strict but it is certainly present. A very strict concept would preclude judges ever acting in an executive capacity, and it would preclude executive servants acting in a judicial capacity. Some very deeply entrenched features of the Canadian legal system are radically inconsistent with a strict separation of powers and the reference procedure is an obvious candidate for interrogation. When a court is asked to answer reference questions, it does so as a lawyer advising a client. The lawyer is the court and the client is the executive that sends the reference. This is why the form of the answer is called an opinion, and not a judgment or a decision. ${ }^{36}$ This is also why the Supreme Court of Canada insists that while it is duty-bound to answer a properly framed question, it has the discretion to decline to answer questions that are not adequately supported by facts or that are posed in a manner that providing an answer would be misleading. ${ }^{37}$ Finally, the client/executive writes the questions, and assuming they meet the minimum conditions of coherence and are supported by necessary factual context, the Court will answer them.

36 The whole concept of a reference is tricky and hard to defend in some ways. It basically converts the government into a client and a court into a legal advisor; that is why there is no "judgment" or "decision." Answers in a reference are the same as any answers in a legal opinion. The difference is that a client may well ignore legal advice, preferring instead to run the risk of not getting caught doing something contrary to law. A government, on the other hand, will always feel bound to follow the legal advice given by the Supreme Court of Canada in a reference opinion: it would be pointless for it to not do so.

37 These are legitimate, if not familiar, objections. While a lawyer would go back to a client to get better instructions before providing an opinion, the Court obviously cannot do so. It is therefore safer to not answer the question at all in those circumstances. 
Or not.

The Supreme Court exercised its discretion to not answer the controversial fourth question, which asked:

Is the opposite sex requirement for marriage for civil purposes as established by the common law and as set out for Quebec in section 5 of the Federal LawCivil Law Harmonization Act, No.1 consistent with the Canadian Charter of Rights and Freedoms? If not, in what particular or what particulars and to what extent? ${ }^{38}$

In explaining this refusal, the Court appears to be a little disingenuous. It says that it must approach the issue as if either a yes or no were possible, when everyone who follows the Court knows full well that this Court has only had one view on laws that discriminate against gays and lesbians: they have no place in a modern constitutional democracy. ${ }^{39}$ Thus it is here that some say the Court failed: it declined to endorse the federal position that the Charter compelled recognition of same-sex marriage. The Court could have written stirring passages that gave the federal government moral and legal cover for its new law, taking some of the pressure off the government in the process. This would have been bold, but when boldness was called for, the Court was timid.

I understand and have some sympathy for this view. It comes from a need to see the Court and its justices as the Herculean ${ }^{40}$ force of normativity. Often the Court is that kind of moral leader. In the Quebec Secession Reference the Court exercised intellectual leadership and careful political acumen. In the early same-sex cases, the Court quickly explained that sexual orientation is like religion and needs to be treated in the same

Supra note 8

39 News Release, "Open Letter to The Hon. Stephen Harper from Law Professors Regarding Same-Sex Marriage" (25 January 2005). The author and 133 other professors of constitutional law signed this letter.

40 I refer here of course to Ronald Dworkin's famous explication of the role of the judge in interpreting the constitution. See Ronald Dworkin, Law's Empire (Cambridge: Belknap, 1986), in which Judge Hercules has superhuman intellectual power and understands judging constitutional cases as requiring an ethical commitment to principled interpretation of the text, as opposed to merely following precedents or discerning what others think is correct. manner: it is not a lifestyle as much as an aspect of being that could only be changed at an unacceptable personal cost that society has no basis to demand of equally respected members of its community. ${ }^{41}$ In Sauvé, the Court granted voting rights to prisoners, and in so doing, provided an extraordinary illustration of the Court's commitment to the principle of protecting minorities against the decisions of a majority that are driven by a judgment of moral worth. ${ }^{42}$ So what gives with the Same-Sex Reference?

I do not think the Court was engaged in an infantile taunting game with the state. While it may be possible to characterize the Court's responses as "You cannot make me" (the state could not actually make them answer and still claim to be committed to a separation of powers), this characterization is hard to square with the previous case law in which the Court compelled the state to stop discriminating against gays and lesbians. $^{43}$ I think that the Supreme Court of Canada meant what it said in the Quebec Secession Reference and Sauvé. In the Quebec Secession Reference, it explained that constitutionalism is fundamentally about protecting minorities from majorities:

Canadians have never accepted that ours is a system of simple majority rule. Our principle of democracy, taken in conjunction with the other constitutional principles discussed here, is richer. Constitutional government is necessarily predicated on the idea that the political representatives of the people of a province have the capacity and the power to commit the province to be bound into the future by the constitutional rules being adopted. These rules are "binding" not in the sense of frustrating the will of a majority of a province, but as defining the majority which must be consulted in order to alter the fundamental balances of political power (including the spheres of autonomy guaranteed by the principle of federalism), individual rights, and minority rights in our society. Of course, those constitutional rules are themselves

\footnotetext{
1 Egan, supra note 2 at para. 5.

42 Sauvé, supra note 3.

See generally, Vriend and Egan, supra note 2.
} 
amenable to amendment, but only through a process of negotiation which ensures that there is an opportunity for the constitutionally defined rights of all the parties to be respected and reconciled.

In this way, our belief in democracy may be harmonized with our belief in constitutionalism. Constitutional amendment often requires some form of substantial consensus precisely because the content of the underlying principles of our Constitution demand it. By requiring broad support in the form of an "enhanced majority" to achieve constitutional change, the Constitution ensures that minority interests must be addressed before proposed changes which would affect them may be enacted. ${ }^{44}$

In Sauvé, over a wounded-sounding dissent, the majority stuck with this theory about constitutionalism, insisting that the state could not deny prisoners the right to vote without undermining its own legitimacy. ${ }^{45}$ The Supreme Court of Canada does therefore see itself as the bulwark against regressive and simple-minded majoritarianism, but it also does not think that it is the only source of rights and justice in Canada. And I think this is a welcome and wise point, which takes me to the final comment I want to make about this case.

\section{DO WE haVE REASONABLE EXPECTATIONS ABOUT CONSTITUTIONS AND THEIR INTERPRETERS?}

All of us - citizens, lawyers, professors, and judges - are always interpreting the Constitution. But we look to courts as the guarantor of rights.

${ }^{44}$ Quebec Secession Reference, supra note 3 at paras. 76-77.

45 Sauvé, supra note 3 at para. 58:

Denial of the right to vote to penitentiary inmates undermines the legitimacy of government, the effectiveness of government, and the rule of law. It curtails the personal rights of the citizen to political expression and participation in the political life of his or her country. It countermands the message that everyone is equally worthy and entitled to respect under the law - that everybody counts .... It is more likely to erode respect for the rule of law than to enhance it, and more likely to undermine sentencing goals of deterrence and rehabilitation than to further them.
We do this for good reason: all the talk of dialogue does not change the hard fact that, absent the use of a section 33 override, the court can stop the conversation if and when it wants, and can do so over the objection of the legislatures affected by its decisions. ${ }^{46}$ But it is a mistake to look only at courts, and a grievous error to think the security of rights rests in the text of a constitution. Many of the positive changes in the lives of gays and lesbians are the result of great court cases, ${ }^{47}$ but many are also the result of legislative reform, ${ }^{48}$ and even more the result of individual and group decisions to simply assert equal moral worth everywhere, without apology and with pride. My point is that rights do not exist in constitutions, or prior to them really. They exist in people and have meaning only if people live in a manner that affirms them, every day. Yes, we need courts, especially to guard against excessive zeal on the part of majorities willing to sacrifice the rights of the few in order to achieve some socially desirable good (such as the case when we lock up those only suspected of terrorist acts to generate the feeling of collective security). But we need people who claim the rights as their own even more. In the long run, rights are lost for a variety of reasons. One main way is when courts refuse to acknowledge a particular claim, ${ }^{49}$ and another is when the particular right being claimed seems to have no purchase on society: when, for example, it cannot bring the necessary social attention to reveal the disadvantaged state of vulnerable people. It may

46 See generally, Chief Justice Catherine Fraser, "Constitutional Dialogues Between Courts and Legislatures: Can We Talk?" (2005) 14:3 Constitutional Forum constitutionnel 7; and Mr. Justice Michel Bastarache, "Courts and Legislatures" (2005) 14:3 Constitutional Forum constitutionnel 1.

47 See e.g., Egan and Vriend, supra note 2. See also M. v. H. [1999] 2 S.C.R. 3, online: CanLII <http://www.canlii.org/ca/ cas/scc/1999/1999scc28.html $>$. Once the Supreme Court of Canada held in Egan and Vriend that it was necessary to see sexual orientation like other grounds of unfair distinction between people, it became necessary for the lawmakers to explain why it is legitimate to exclude gays and lesbians from any social practice.

48 See e.g., Canadian Human Rights Act, R.S.C. 1985, c. H-6, s. 3. Also recall the famous statement by Prime Minister Trudeau on 21 December 1967: "There's no place for the state in the bedrooms of the nation," referring to the upcoming decriminalization of "homosexual acts." See "Trudeau's Omnibus Bill: Challenging Canadian Taboos," online: CBC Archives <http://archives.cbc.ca/IDD-1-73-538/politics economy/omnibus/>.

49 See e.g., Gosselin v. Quebec (Attorney General), [2002] 4 S.C.R. 429, 2002 SCC 84, online: CanLII <http://www.canlii. $\mathrm{org} / \mathrm{ca} / \mathrm{cas} / \mathrm{scc} / 2002 / 2002 \mathrm{scc} 84 . \mathrm{html}>$, where the Court rejected a claim for constitutional protection of basic social security entitlements. 
well be that rights have a limited lifespan and that, in the future, a different concept will have more power to effect the kind of social and political changes required for a world that is more respectful of the needs and aspirations of each person. For now, we have rights. And while they may be mythical, rights are a myth that many in the world wish they had and for which we in Canada are fortunate.

It does not bother me then that the Court stepped out of the limelight and let the same-sex couples play the starring role by referring to the unappealed decisions. In following this course, the Court pushed the government to figure out a better and more ennobling defence for its law, rather than allowing it to claim that it was simply following the orders of the judiciary. Perhaps the legislatures should become comfortable with saying that they are passing the law because they ought to do so on principle. And sometimes for a Court to be Herculean means to shut up. No doubt the Court would strike down a law that, like laws restricting prisoners' voting rights, appealed to the capacity of a majority to pass judgment about the moral worth of gays and lesbians by denying them access to a basic social institution. But the Supreme Court of Canada was not required to defend gays and lesbians in this case it has been in so many others, and the federal government properly decided to stop fighting against, and started arguing for, those rights. ${ }^{50}$ The Court was required to defend the division of legislative authority between the two levels of government and it did that in unambiguous terms.

\section{CONCLUSION}

In an early passage in the Same-Sex Reference the Court explains that with progressive or liberal interpretation of the constitution by courts, "our Constitution succeeds in its ambitious enterprise, that of structuring the exercise of power by the organs of the state in times vastly different from those in which it was crafted." ${ }^{51}$ It is a difficult project, and not one that is error-free. But this judgment is largely just that: a calm, even, and measured response that walks away from a social debate of great heat and little light. At the end of the day, the holding in the case is the obvious one: the federal government, with its legislative power over marriage, is free to act on principle and no longer deny access to the institution of marriage simply because the two people willing to make a public promise to love one another happen to be of the same sex. The only problem is that because it is so obvious, I may not bother to include the case in the course material at all.

\section{Ronalda Murphy \\ Associate Professor \\ Faculty of Law, Dalhousie University \\ Ronalda.Murphy@Dal.Ca}

\footnotetext{
50 This could not be made clearer than in the factum filed by Professor Hogg and Michael H. Morris on behalf of the federal government. See Peter W. Hogg \& Michael H. Morris, "Factum of the Attorney General of Canada," online: Justice Canada $<$ http://www.justice.gc.ca/en/dept/pub/factum/factum.html $>$, and Peter W. Hogg \& Michael H. Morris, "Supplementary Factum of the Attorney General of Canada," online: Justice Canada <http://www.justice.gc.ca/en/dept/pub/factum/supp/ body.html $>$.
} 